\title{
EFFECTS OF EPS, DER, TATO, ON ROA IN THE HOTEL, RESTAURANT AND TOURISM SECTOR
}

\author{
Dian Primanita Oktasari \\ Management Study Program \\ Faculty of Economic and Business \\ Universitas Mercu Buana
}

Article DOI: https://doi.org/10.36713/epra4333

\begin{abstract}
This study aims to determine the effect of earnings per share, debt to equity ratio, and total asset turnover, on return on assets in companies listed on the Indonesia Stock Exchange, hotels, restaurants and tourism sub-sectors in 2013-2017. The independent variables in this study are earnings per share, debt to equity ratio, and total asset turnover, while the dependent variable is return on assets. The sample selection in this study used the saturated sample method and obtained 7 companies as samples. Research data obtained from the Indonesia Stock Exchange. The method used in this study is panel data regression and found that the more appropriate model used is the common effect. The results of this study indicate that earnings per share and debt to equity ratio have a positive and significant effect on return on assets and total asset turnover has a negative and significant effect on return on assets.
\end{abstract}

\section{INTRODUCTION}

One of the sub-sectors listed on the Indonesia Stock Exchange is the hotel, restaurant and tourism sub-sector. The hotel, restaurant and tourism sub-sector in Indonesia is one of the sub-sectors that has great potential to support the country's economy. Various tourist sites with a variety of inherent cultures can be found throughout the Motherland region attracting the attention of visitors, both local and foreign tourists. This has become a strength for the development of tourism in Indonesia to date. On the other hand, the current global era accompanied by the rapid development of technology has then invited the attention of various industrial sectors to utilize Information and Communication Technology (ICT) to raise their performance, including in the hotel, restaurant and tourism sectors.

Figure 1.

Number of Foreign Tourists Visiting Indonesia

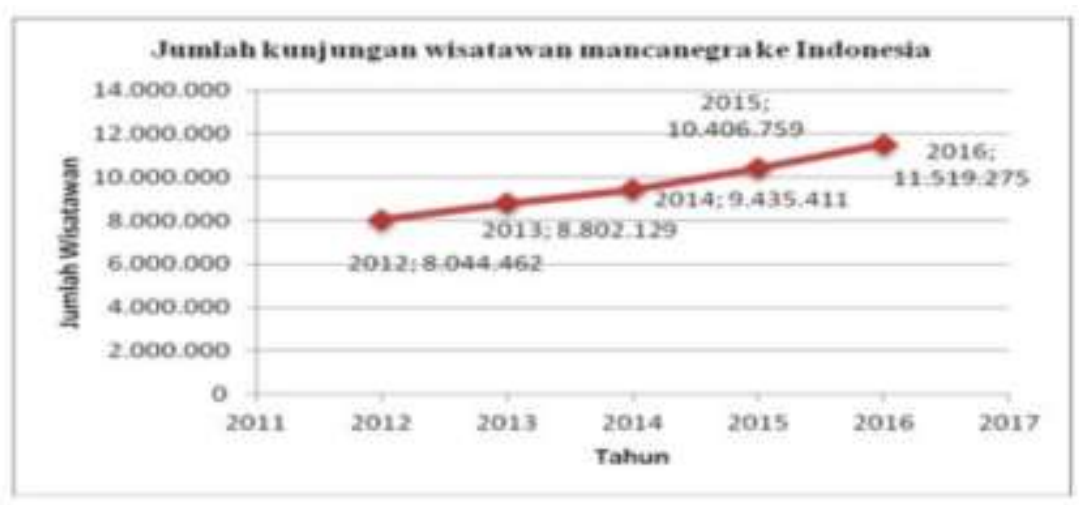

Source : (Ministry of Tourism, secondary data is processed, 2017) 
Figure 1. shows the increasing number of foreign tourists entering Indonesia each year. The increase in the number of foreign tourists entering Indonesia will have an impact on increasing revenues in the hotel, restaurant and tourism sub-sector companies, thus increasing company value. High company value will make the market believe not only in the company's current performance but in the company's prospects in the future, so that the company's shares will also be much in demand by investors. (source: Ministry of Tourism)

In 2016 tourism contributed $10 \%$ of national GDP, with the highest nominal in ASEAN. National tourism GDP grew by $4.8 \%$ with an upward trend of $6.9 \%$, far higher than the agriculture, automotive manufacturing and mining industries. The tourism industry is still ranked fourth national foreign exchange contributor, by $9.3 \%$ compared to other industries. The highest growth of tourism foreign exchange revenue was $13 \%$. The tourism sector is the most profitable business in generating foreign exchange. Tourism is a potential sector that must be developed and maintained to encourage the development of a country or tourist area. With the development of the tourism industry in Indonesia, it can attract investors to invest in the tourism, hotel and restaurant subsectors by investing in the capital market. (Source: CNN Indonesia)

Research conducted by Rahma (2016) $\mathrm{CR}$ has a positive and significant influence on company performance; DER has a negative and significant effect on company performance; TATO has a positive and significant effect on company performance. While simultaneously

Tabel 1.

Retrun On Asset Sectors of Hotels, Restaurants, and Tourism Registered on the Stock Exchange in 2013-2017

\begin{tabular}{clrrrrr} 
No & Kode Perusahaan & $\mathbf{2 0 1 3}$ & $\mathbf{2 0 1 4}$ & $\mathbf{2 0 1 5}$ & $\mathbf{2 0 1 6}$ & $\mathbf{2 0 1 7}$ \\
\hline \hline 1 & JSPT & 0.06 & 0.09 & 0.06 & 0.04 & 0.04 \\
2 & FAST & 0.08 & 0.01 & 0.05 & 0.07 & 0.06 \\
3 & ICON & 0.09 & 0.02 & 0.01 & 0.01 & 0.04 \\
4 & INPP & 0.01 & 0.03 & 0.02 & 0.04 & 0.02 \\
5 & JIHD & 0.27 & 0.02 & 0.01 & 0.05 & 0.03 \\
6 & MAMI & 0 & 0 & 0 & 0.02 & 0.02 \\
7 & KPIG & 0.03 & 0.06 & 0.02 & 0.13 & 0.09 \\
8 & PANR & 0.04 & 0.04 & 0.13 & 0 & 0.29 \\
9 & PDES & 0.04 & 0.05 & 0.17 & 0.05 & 0.3 \\
\cline { 2 - 6 } & RATA-RATA & 0.07 & 0.04 & 0.05 & 0.05 & 0.10
\end{tabular}

Source: (IDX data processed, 2019)

From the table above it can be seen that the average retrun on assets increased from 0.07 to 0.10 from the industry. experienced a significant increase of 0.09 from 0.06 and in 2015 decreased with a value
$\mathrm{CR}$, DER, and TATO have a significant influence on company performance.

The reason researchers chose the dependent variable $(\mathrm{Y})$ based on several journals read by researchers, that previous researchers put the dependent variable $(\mathrm{Y})$ is retrun on assets (ROA), stock prices, retrun shares and firm value. The researcher looked at the independent variable $(\mathrm{X})$ taken by the previous researcher from several ratios such as cash ratio, current ratio, DER, DAR, NPM, TATO, EPS, PER, PVB, company size, dividend, sales, and NPM. This study uses hotel, restaurant and tourism sub-sector companies listed on the Indonesia Stock Exchange in 2013-2017. Many tourism destinations in Indonesia have interesting places, including beautiful inland areas, interesting cultural ruins and beaches and mountains. Therefore hotels, restaurants and tourism companies large and small have good prospects going forward.

The following table is the return on asset data from 9 Hotels, Restaurants and Tourism subsectors listed on the Indonesia Stock Exchange in 2013-2017: of 0.06 and in 2016 to 2017 decreased 0.04. The development of retrun on assets of PT Panorama Sentrawisata Tbk (PANR) continues to increase every year, in 2013 to 2014 the retrun on assets was 
EPRA International Journal of Multidisciplinary Research (IJMR) - Peer Reviewed Journal Volume: 6 | Issue: 5 | May 2020 || Journal DOI: 10.36713/epra2013 || SJIF Impact Factor: 7.032 ||ISI Value: 1.188

0.04 and experienced a significant increase of 0.13 in 2015 and decreased in 2016 and experienced a very

significant increase of 0.29 .

Figure 2.

Average Return on Assets in the Tourism, Hotel and Restaurant Sub Sectors Listed at the 2013-2017 Indonesia Buersa Securities

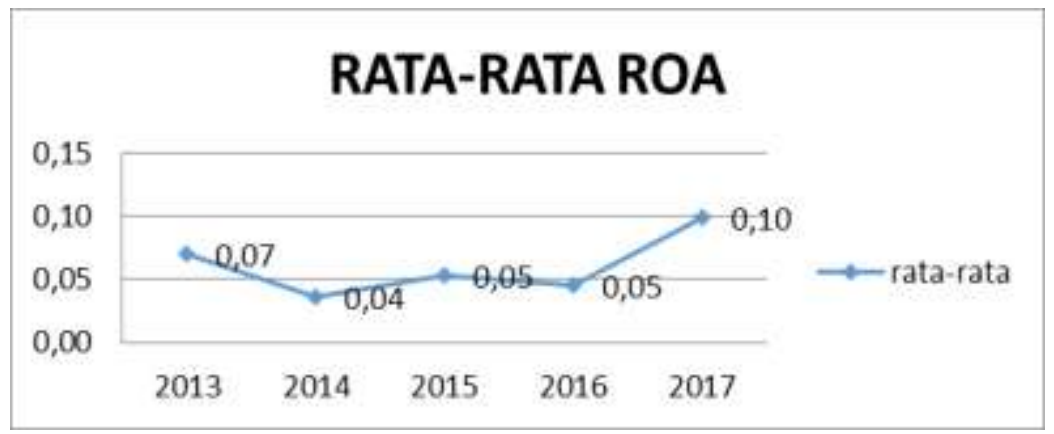

Source: www.idx.co.id(2019)

Based on sources from the financial statements in the Hotels, Restaurants and Tourism sub-sectors from 2013 to 2017 (source: Indonesian stock exchange), it was explained that the retrun on assets in 2014 experienced a sharp decline, due to an increase in projects in implementation and also an increase cash balances and cash equivalents, the payment of fees for obtaining permits and land acquisition by a subsidiary and the purchase of restaurant equipment and equipment. In 2017 experienced a sharp increase, due to an increase in real estate business revenue and an increase in average room rates, occupancy rates and an increase in food and beverage sales (source: Kontan.co.id Jakarta).

Figure 3.

Earning Per Share in the Hotel, Restaurant and Tourism Sub Sectors Listed on the Indonesia Stock Exchange in 2013-2017

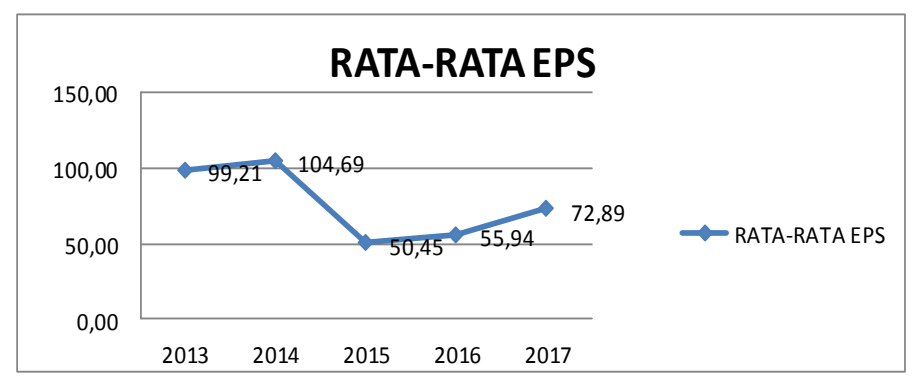

Source www.idx.co.id(2019)

In figure 3, that earnings per share in 2015 decreased to 50.45 and started to increase again in 2017 by 72.89 , it can be said that investors will be more interested in stocks that have high EPS compared to stocks that have low EPS, low EPS tends to make stock prices down. 
Figure 4.

Debt To Eqity Ratio of Hotel, Restaurant and Tourism Sectors Registered on the Indonesian Stock Exchange in 2013-2017

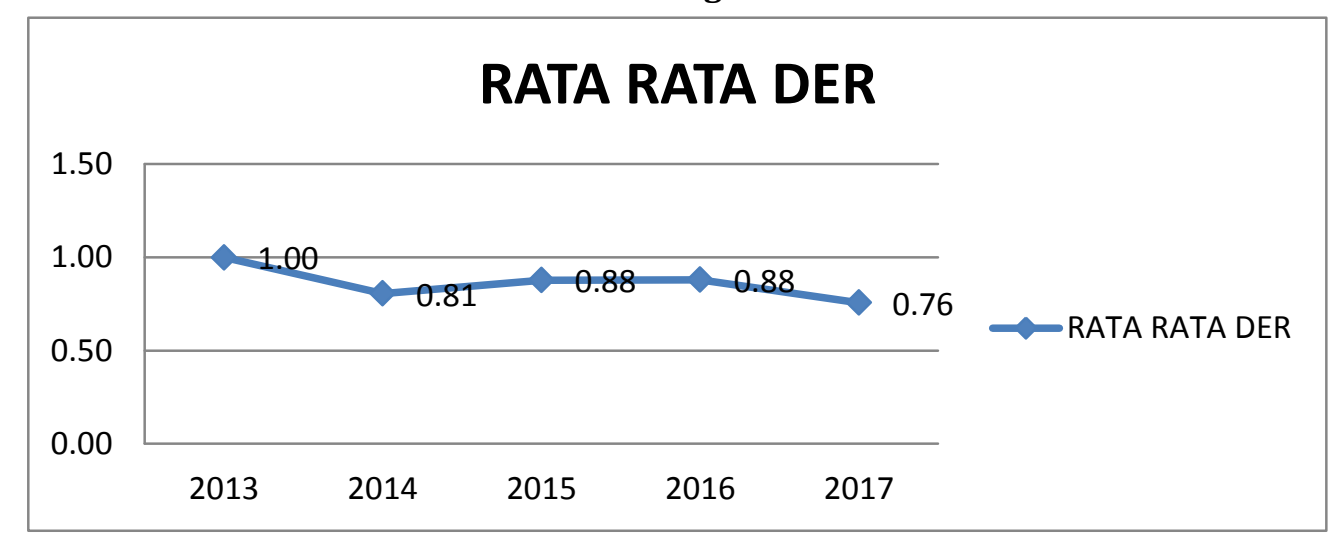

Source www.idx.co.id(2019)

In Figure 1.4 explains the average DER in the hotel, restaurant and tourism sub-sectors listed on the Indonesia Stock Exchange in the period 20132017 experienced ups and downs (fluctuations) which tends to fall, can be seen DER 2013 ratio that can be 1.00 , in 2015 and 2016 decreased by 0.88 , and in 2017 decreased again by 0.76 .

Research conducted by Mandasari (2016) shows that DER has a positive effect on PER, on the other hand Andrian's research (2016) shows that DER has a positive and not significant effect on PER.

The lower the DER, the greater the amount of owner's capital that can be presented as a debt guarantee. Conversely, if the higher the DER, the smaller the amount of owner's capital that can be used as debt collateral. If the ratio increases, this means that the company is financed by creditors and not from its own financial sources which may be a fairly dangerous trend. Lenders and investors usually choose a low Debt to Equity Ratio because their interests are better protected if there is a decline in business at the company concerned. (Budi Kho, 2017).

Figure 5.

Average Total Trunover Assets in the Hotel, Restaurant and Tourism Sub Sectors Listed at the 2013-2017 Indonesian Buersa Securities

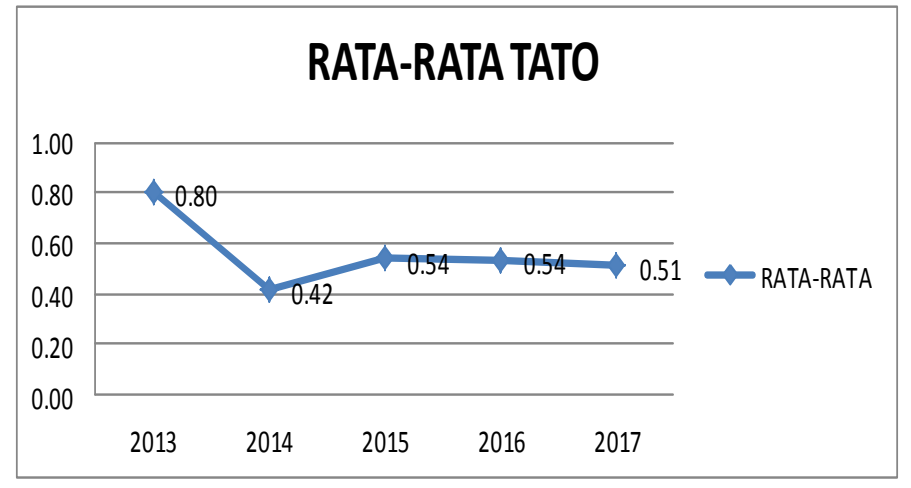

Source www.idx.co.id(2019)

In Figure 1.5, hotel, restaurant and tourism companies in 2013 had a total asset turnover ratio of 0.80 , producing assets that could spin and gain profits and aimed at more efficient use of overall assets in generating sales. In 2014 a decline in the total assets turnover ratio of 0.42 resulted in a lack of efficient use of all assets in generating sales. In 2015, the total assets of the trunover increased again to 0.54 until 2016, in other words, the same amount of assets can increase sales volume if the total asset turnover is increased or enlarged. 


\section{LITERATUR REVIEW \\ Financial Management}

Financial management is an amalgamation of science and art that discusses, examines and analyzes how a financial manager uses all company resources to find, manage and share funds with the aim of being able to provide profit or prosperity for shareholders and suistainability or to the company's continued business (Irham Fahmi, 2014).

\section{Financial Ratios.}

Understanding Financial Ratios according to Ross (2015) Financial ratios are one number divided by other numbers and because there are so many accounting numbers, we can test a large number of various possible ratios. Kasmir (2014) explains the financial ratio analysis is the activity of comparing the numbers in the financial statements by dividing one number with another number. Comparisons can be made between one component with components in one financial statement or between components that exist between financial statements. The financial ratio is expected to be used to detect financial difficulties (Oktasari, 2019).

\section{Benefits of Ratio Analysis.}

According to Fahmi (2014) the benefits are as follows: (1) Financial ratio analysis is very useful to be used as a tool to assess the performance and presentation of the company; (2) Financial ratio analysis is very useful for management as a reference for planning; (3) Financial ratio analysis can be used as a tool to evaluate the condition of a company from a financial perspective; (4) Financial ratio analysis is also useful for creditors which can be used to estimate the potential risks that will be faced.

Form of financial ratios. According to Brigham and Houston (2014), the forms of financial ratios are as follows:

\section{a)Liquidity Ratio}

Understanding the liquidity ratio according to Syafrida Hani (2015) the company's ability to meet obligations to be disbursed or past due. Liquidity, the availability of funds owned to meet all debts that are due and according to Rambe (2015). Liquidity ratio is the ratio used to measure a company's ability to meet its short-term financial obligations. By linking the amount of cash in other current assets with short-term liabilities can provide an easy and fast measure used in measuring liquidity. 2 liquidity ratios that are commonly used are quick ratio and current ratio.

According to Firdaus (2017) liquidity ratios affect the company's financial performance, so this ratio has a relationship with the company's stock price.

\section{b) Solvability Ratio}

The solvability ratio according to Kasmir (2014) is "the ratio used to measure the extent to which a company's assets are financed with debt." In a broad sense it is said that the solvency ratio is used to measure the ability of a company to pay all obligations, both short-term and long-term if the company is dissolved (liquidated).

To measure the extent to which companies are financed with debt one of them can be seen through Debt to Equity Ratio (DER). Debt to Equity Ratio (DER) is one of the ratios used to measure the level of company solvency (Dewi, 2015). According to Kasmir (2014), it states that "Debt to Equity Ratio (DER) is a ratio used to determine the ratio between total debt and capital. This ratio is useful to find out how much the company's assets are financed from debt. Ratio as an indicator that debt can be paid with assets. Namely with the condition of a small ratio, the better.

\section{c) Profitability Ratio}

Profitability ratios according to Kasmir (2014) are "Ratios to assess a company's ability to seek profits. According to I Made Sudana (2015), it is stated that Return on Assets (ROA) is a ratio that shows how much net income can be obtained from all the assets owned by the company . Therefore used after-tax profit figures and the average wealth of the company. Thus this ratio connects the profits derived from the company's operations with the amount of investment or assets used to produce these operating profits. Return on Assets (ROA) focuses the company's ability to obtain earnings in the company's operations (Oktasari, 2019).

\section{d) Market Value Ratio.}

Understanding Earning Per Share (EPS) according to Kasmir (2014) is "a ratio to measure the success of management in achieving profits for shareholders." The higher the value of EPS is certainly encouraging shareholders because the greater the profit provided to shareholders. Earnings ratios show the combined impact of liquidity and asset and liability management on a company's ability to generate profits. So, it was concluded that EPS is a ratio that shows the amount of profit obtained from each existing stock. Porphyability or profitability ratios play an important role in assessing the condition of companies related to how to make financial statements related to earnings so that the performance and function of financial statements can be seen by companies with good management so they can utilize various assets and assets to achieve maximum profit according to financial accounting standards. 


\section{e) Activity Ratio.}

Activity ratio is the ratio used to measure the effectiveness of a company in using its assets. Total Assets Turn Over according to Kasmir (2014) is: "Measuring the number of times the total assets of a company generate sales, this can also be interpreted Total Assets Turnover measures turnover all assets owned by the company and measure how many sales are obtained from each rupiah of assets ". The activity ratio is associated with the company's activities to generate profits. Every company would want to get the maximum profit with minimal costs so that the cost collection method also plays an important role.

Figure 6.

Framework

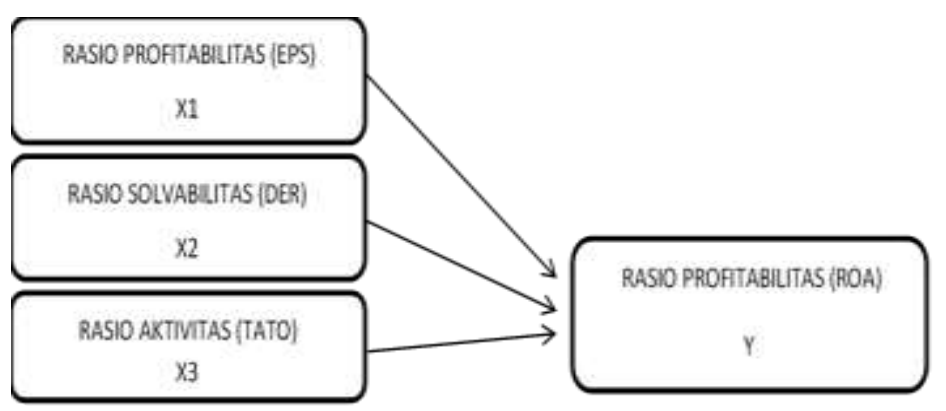

\section{Hypothesis}

The research hypothesis is a temporary answer to the problem under study, where the truth needs to be empirically tested is as follows:

H1: EPS has a significant effect on ROA

H2: DER has no significant effect on ROA

H3: TATO has a significant effect on ROA

\section{RESEARCH DESIGN AND METHOD}

Research design. The research design used is causal research, according to Sugiyono (2016) that is, a causal relationship. This causal research is a research to find out the influence between one or more independent / independent variables (Earning Per Share, Debt to Equity Ratio, and Total Asset Turnover) on the dependent / dependent variable (Return On Asset).

Variable Definition and Operationalization. Research Variable is something in the form of what is determined by researchers to be studied and obtained information and conclusions can be drawn (Sugoyino, 2016). This study has two variables, namely the related variable (dependent) and the independent variable (independent). The variables used in the study, the dependent variable about Return On Assets. Then, the independent variable consists of Earning Per Share, Debt to Equity Ratio, and Total Asset Turnover.

Dependent Variable. According to Sugiyono (2016), the Related Variable (the dependent variable) is the variable that is affected or which is due to the independent variables (independent variables). The dependent variable as the $\mathrm{Y}$ variable used in this study is Return On Assets. The way to measure this ratio is as follows:

$$
\text { ROA }=\text { EAT } / \text { total assets }
$$

Independent Variable. According to Sugiyono (2016), the independent variable (independent variable) is a variable that influences or is the cause of changes or the emergence of the dependent variable (the dependent variable). In this study there are 3 independent variables used, namely Current Ratio, Debt to Equity Ratio and Return on Assets.

Earning per share. Understanding Earning Per Share (EPS) according to Kasmir (2012) is "a ratio to measure the success of management in achieving profits for shareholders. Earning per Share (EPS) is a comparison between the revenue generated (net income) and the number of shares outstanding (Gitman, 2012).

EarningPer Share $=$ Net Income $/$ outstanding shares.

Debt to Equity Ratio. Leverage ratios are ratios intended to measure how much the company's assets are financed with debt (Mardika, 2016). Debt to Equity Ratio can be formulated as follows:

$$
\text { DER = total debt } / \text { total equity }
$$

Total Assets Turnover. Total Assets Turn Over Cashmere (2014) is: "Shows how the effectiveness of the company uses the overall assets to create sales and make a profit. ". The formula to look for TATO is as follows:

TATO $=$ Sales $/$ Total Assets 


\section{Research population.}

Population is a generalization area that consists of objects or subjects that have certain qualities and characteristics determined by researchers to be studied and then drawn conclusions. Sugiyono (2014). So the population is not only people, but also objects and other natural objects. the population used in this study is the hotel, restaurant, and tourism sub-sectors listed on the Indonesia Stock Exchange (BEI) in 2013-2017, with the criteria used are companies in the hotel, restaurant and tourism sub-sectors listed on the IDX at in 2013-2017 and has normal data of 9 companies. Due to 5 years of observation, 45 data popups.

\section{Research sample.}

The sample method used is saturated sample which aims to get a sample that is in accordance with the research objectives. Which has in this study the number of samples is 45 samples.

\section{Analysis Method.}

This research uses panel data regression analysis method with the help of software Eviews 9 . Activities in data analysis are grouping data based on variables and types of respondents, tabulating data based on variables from all respondents, presenting data for each variable studied, doing calculations to answer the problem formulation, and perform calculations to test the hypotheses that have been submitted then processed to determine the effect of the research variables using the Eviews 9 program.

\section{RESEARCH RESULTS AND DISCUSSION Descriptive Statistics Results}

\begin{tabular}{lcccc}
\multicolumn{5}{c}{ Tabel 2. Descriptive Statistics } \\
\hline Mean & ROA & EPS & DER & TATO \\
Median & 15,38850 & 1,406312 & 2,722578 & 5,333333 \\
Maximum & 12,84772 & 1,369274 & 2,273806 & 4,000000 \\
Minimum & 34,01487 & 2,005966 & 5,666057 & 15,00000 \\
Std. Dev. & 2,040493 & 1,002252 & 0,936466 & 1,000000 \\
& 7,819159 & 0,225783 & 1,347503 & 3,346640 \\
Observations & 35 & & & \\
\hline
\end{tabular}

Based on the results of data processing in Table 2 above, it can be seen that $\mathrm{N}=35$, Return on Assets (ROA) has a mean value of 15.3885 with the highest value of 34.01487 and the lowest of 2.040493. Debt To Equity Ratio (DER) has a mean value of 1.406312 with the highest value of 2.005966 and the lowest value of 1.002252 . Total Asset Turnover (TATO) has a mean value of 2.7722578 with the highest value of 5.666057 and the lowest value of 0.936466 . Earning Per Share (EPS) has a mean value of $5.3333 \%$ with the highest value of $15 \%$ and the lowest value of 1.00 million.

\section{Results of Panel Data Model Selection Common Effect Model test}

This method is the simplest method for estimating panel data regression models with the assumption of intercepts and constant regression coefficient (slope) between time and across individuals. In this approach does not pay attention to the dimensions of time and individuals, so it can be assumed that the behavior of data between companies is not different or will remain the same in various periods of time. The results of processing Eviews 9.0 obtained the following results: 


\section{Tabel 3. Common Effect Model test Results}

Dependent Variable: ROA

Method: Panel EGLS (Cross-section random effects)

Date: 11/09/18 Time: 14:09

Sample: 20132017

Periods included: 5

Cross-sections included: 7

Total panel (balanced) observations: 35

Swamy and Arora estimator of component variances

\begin{tabular}{ccccc}
\hline \hline Variable & Coefficient & Std. Error & t-Statistic & Prob. \\
\hline \hline C & 31.48466 & 9.982828 & 3.153882 & 0.0035 \\
EPS & 4.931084 & 0.419882 & -0.756315 & 0.0455 \\
DER & 1.137033 & 0.338991 & -1.094363 & 0.0282 \\
TATO & -1.137347 & 0.440521 & -2.581822 & 0.0146 \\
\hline \hline
\end{tabular}

Effects Specification

S.D. Rho

\begin{tabular}{lll} 
Cross-section random & 0.799383 & 0.8371 \\
Idiosyncratic random & 0.352698 & 0.1629 \\
\hline
\end{tabular}

Weighted Statistics

$\begin{array}{llll}\text { R-squared } & 0.256450 & \text { Mean dependent var } & 15.38850 \\ \text { Adjusted R-squared } & 0.186743 & \text { S.D. dependent var } & 7.819158 \\ \text { S.E. of regression } & 7.051378 & \text { Sum squared resid } & 1591.102 \\ \text { F-statistic } & 3.678934 & \text { Durbin-Watson stat } & 2.136284 \\ \text { Prob(F-statistic) } & 0.022040 & & \end{array}$

Based on table 3. random effect test results, obtained the following equation:

ROA = C 4.931084 EPS - 1.137033 DER - 1.137347 TATO

Based on the adjusted value (R2) in Table 3, the common effect test results of $18.67 \%$, can be interpreted that the earning per share, debt to equity ratio, and total asset turnover can explain its relationship to the price earning ratio, while the remaining $81.33 \%$ explained by other variables outside the research model. 


\section{Hypothesis test}

T test. Based on Table 3 the results of the common effect test that contains the results of the $t$ test by looking at the t-statistic and probability values can be explained as follows:

Effect of Earning Per Share (EPS) on Return on Assets (ROA). Based on the test results above, it can be seen that Earning Per Share (EPS) has a positive and significant effect on Return On Assets (ROA). The increase in EPS indicates that the company has succeeded in increasing the level of investor prosperity, and this will encourage investors to increase the amount of capital invested in the company.

In accordance with Husnan's research (2015) this ratio is considered by investors in choosing stocks. The company has a high EPS value, it will show a high market value as well, so that the stock will be in demand by investors and will have an impact on rising stock prices, and vice versa if the company has a low EPS will also show a low market value, so it will have an impact on decline in the price of these shares.

Effect of Debt To Equity Ratio (DER) on Return On Assets (ROA). Based on the test results above, it can be seen that the debt to equity ratio (DER) has a positive and significant effect on Return On Assets (ROA). This is supported by Mahardika (2016) research showing that partially CR, DER has a positive and significant effect on ROA but according to the results of research conducted by Nelsi Anggraini (2017) shows that DER has no significant effect on ROA.

Debt to equity ratio (DER) is one of the solvency ratios. DER is the ratio used to assess debt to equity. This ratio is sought by comparing all debt including current debt with all equity (Sartono, 2014). The higher the DER shows the higher the use of debt as a source of corporate funding. This can pose a significant risk for the company when the company is unable to pay these obligations when due, so that it will disrupt the continuity of the company's operations.

Total Asset Turnover (TATO) to Returm On Assets (ROA). Based on the test results above, it can be seen that the Total Asset Turnover (TATO) has a negative and significant effect on Returm On Assets (ROA).

Total Asset Turnover shows the level of efficiency in using all assets of the company in generating certain sales volumes. The higher the Total Asset Turnover Ratio means the more efficient use of overall assets in generating sales. The same amount of assets, can increase sales volume if the Total Asset Turnover is increased or enlarged. TATO is important for creditors and company owners but will be even more important for company management because this will show the efficient use of all assets in the company (Syamsuddin, 2011).

The coefficient of determination (R2). Based on the adjusted value (R2) in table 4.2 random effect test results of $28 \%$, it means that earnings per share, debt to equity ratio, and total asset turn over can explain its relationship to return on assets, while the remaining $72 \%$ is explained by variables Other variables outside the research model.

\section{CONCLUSIONS}

Based on the above research results can be concluded as follows: 1) earnings per share has a positive and significant effect on return on assets in companies in the hotel, restaurant and tourism subsectors in 2013-2017. In other words EPS affects ROA. 2) Debt to equity ratio has a positive and significant effect on return on assets in companies in the hotel, restaurant and tourism sub-sector in 20132017. In other words DER has no effect on ROA. 3) Total Asset Turnover has a negative and significant effect on return on assets in the hotel, restaurant and tourism sub-sector in 2013-2017. In this case the company must increase the value of TATO in order to attract investors to invest their capital in the form of shares.

\section{REFERENCES}

1. Asiah, Antung Noor. 2014. Pengaruh Intellectual Capital Terhadap Profitabilitas (Studi Empiris pada Lembaga Keuangan). Jurnal Spread. Vol. 4 No. 1.

2. Brigham, Eugene $F$ \& Joel F. Houston. (2014). Dasar-Dasar Manajemen Keuangan Buku 1 dan 2. Edisi Kesebelas. Jakarta: Salemba Empat.

3. Dewi, Ni Kadek Venimas Citra . Cipta,Wayan dan Kirya, I Ketut. 2015. Pengaruh LDR, LAR, DER dan CR Terhadap ROA. E-Journal Bisma Universitas Pendidikan Ganesha. Vol. 3.

4. Fahmi, Irham. 2014. Analisa Laporan Keuangan. Bandung: Alfabet.

5. Firdaus, Iwan., Sediaz, Sri Ramahan Bagus. (2017). Pengaruh Profitabilitas, likuiditas dan struktur modal terhadap Kebijakan Dividen (Studi Perusahaan pada Sub Sektor Perdagangan Eceran di Bursa Efek Indonesia Periode 2011-2015). Jurnal Ilmiah Manajemen dan Bisnis, Vol. 3.No.3.

6. Husnan Suad. (2015). Dasar-Dasar Manajemen Keuangan. Edisi Keenam. Yogyakarta: UPP STIM YKPN.

7. Kasmir. 2014. Analisa Laporan Keuangan. Edisi satu, cetakan ketujuh. Jakarta : PT Raja Grafndo Pesada.

8. Lutfi, Muslich \& Jessi Arsitha. (2016). The Analysis of Factors Affecting Price Earning Ratio on the Company Shares Registered in Jakarta Islamic Index. Academic Journal of Economic Studies. 2(3), 55-63.

9. Mandasari, Putri. (2016). Pengaruh DPR, DER, dan ROA Terhadap PER Pada Perusahaan 
Sektor Barang Konsumsi Yang Terdaftar di BEI. Jurnal Profita 2(7), 1-12.

10. Mardika, P.A dan Marbun, D.P (2016). "Pengaruh CR dan DER Terhadap ROA (Studi Pada Perusahaan dari Industri Perbankan Tahun 2008-2015)".Jurnal Widyakala. Vol.3.

11. Oktasari,Dian Primanita \& Parashakti.(2019). Analisis Rasio Keuangan Sebagai Alat Prediksi Kemungkinan Kebangkrutan Pada Perusahaan Textil Dan Garment Yang Tercatat Di BEI. Jurnal Ilmiah Manajemen dan Bisnis.Vol 5.No.2

12. Oktasari,Dian Primanita \& Widyanty.(2019). Financial Ratio Analysis as a Prediction Tool of Bankruptcy on Banking Companies Listed in Indonesia Stock Exchange. European Journal of Business and Management.Vol 11.No.15.

13. Rahmah, Amrita Maulidia. 2016. Pengaruh Likuiditas, Solvabilitas, dan Aktivitas terhadap Profitabilitas pada Perusahaan Otomotif yang Terdaftar di Bursa Efek Indonesia Periode 20122014. e-Journal Bisma Universitas Pendidikan Ganesha Jurusan Manajemen .Vol 4.

14. Ross, Stephen A., Randolph W. Westerfield., Bradford D. Jordan \& Ruth Than. (2015). Fundamentals of Corporate Finance $\left(2^{\text {th }}\right.$ Ed.). New York: McGraw-Hill/Irwin.

15. Sudana,I Made. 2015. Manajemen Keuangan Perusahaan. Jakarta: Erlangga.

16. Sugiyono, Prof.Dr. 2014. Metode Penelitian Pendidikan Pendekatan Kuantitatif, Kualitatif dan $R \& D$. penerbit Alfabeta.

17. Suroto. (2015). Analisa Faktor-faktor Yang Mempengaruhi Price Earning Ratio Perusahaan Manufaktur Yang Terdaftar di Bursa Efek Indonesia Periode 2010-2012. Prosiding Seminar Nasional\& Cell for Papers 2015. p176-194

18. Wartono,Tri. (2018). Pengaruh current ratio (CR) dan debt to equity ratio (DER) terhadap retrun on asset (ROA), (Studi pada PT Astra International, Tbk).

19. http://www.kemenpar.go.id/categories/laporankinerja

20. https://www.cnnindonesia.com/wisata/indeks/64

21. https://www.idx.co.id/

22. https://www.kontan.co.id/ 